\title{
Broadening the British idealist approach to human rights: J. S. Mackenzie's list of political, economic, and social rights
}

\section{Nazli Pinar Kaymaz}

To cite this article: Nazli Pinar Kaymaz (2021) Broadening the British idealist approach to human rights: J. S. Mackenzie's list of political, economic, and social rights, Journal of Human Rights, 20:5, 564-579, DOI: $10.1080 / 14754835.2021 .1969226$

To link to this article: https://doi.org/10.1080/14754835.2021.1969226

\section{Published online: 13 Oct 2021.}

Submit your article to this journal $\widetilde{ }$

\section{山 Article views: 70}

Q View related articles $\asymp$

\section{View Crossmark data $₫$}




\title{
Broadening the British idealist approach to human rights: J. S. Mackenzie's list of political, economic, and social rights
}

\author{
Nazli Pinar Kaymaz
}

\begin{abstract}
Although an extensive literature on the British idealist theory of human rights exists, it is limited by its focus on prominent British idealist philosophers and its predominant interest in civic and political rights. This article broadens our understanding of the subject by examining the lesser-known British idealist John Stuart Mackenzie's work on economic and social human rights. Mackenzie's reflections on the matter appear to be significant as an early example of employing human rights language as a solution to widespread poverty and destitution in Britain. His use of a tripartite idealist perception of human nature allows Mackenzie to underline the complexity of human potential and human need that must be protected in all spheres of social interaction. In light of ongoing challenges to the legitimacy of economic and social rights as human rights, Mackenzie's work constitutes a solid example of a maximalist approach to human rights that aims to not merely ensure survival but leads to the realization of a truly human life.
\end{abstract}

\section{Introduction}

Since the 1990s, we have witnessed a revival of interest in British idealism and its unique theoretical approach to civic and human rights. ${ }^{1}$ Although T. H. Green's work on rights informs most of the discussion on the British idealist rights theory, a growing body of literature also recognizes other idealists' contributions at the turn of the twentieth century. As Mander (2011, p. 3) identified, unlike many other schools of thought, there was "a deep and wide-ranging unity of thought" among the British idealists, and this unity was perhaps most apparent in their approach to the concept of rights.

For the British idealists-whose work was inspired by German idealists like Kant and Hegel in addition to ancient Greek philosophers such as Plato and Aristotle-rights were powers that stem from an individual's potential for moral self-realization and subsequently were recognized and maintained by the state for the common-good of the society. Thus, rights according to the British idealists, had both a moral, natural aspect and a communitarian, historical property. They perceived rights to be natural "not in the sense that they actually exist when a man is born ... but that they arise out of, and are necessary for the fulfilment of a moral capacity without which a man would not be a man" (Green, 1895, p. 47). British idealists argued, consistent with the Aristotelian conception of man as a "political animal," that humans could be perceived as the subjects of rights only when they are part of a community in pursuance of a common good. A moral right was truly actualized only when members of a political community developed the habit of recognizing the legitimacy of such a right for themselves and others and after this habit was formally codified in the laws of the state. Thus, idealists' understanding of rights was a 
historical and evolutionary one, dependent on the expectation that communities were meant to embody fuller realizations of moral rights over time.

Although British idealists agreed for the most part on the moral basis of rights and the process of rights recognition that gave them "fuller reality" (Green, 1895, p. 138), their reflections on the exact rights that should be recognized in a just community showed some variation. Whereas earlier British idealists' seminal works primarily dealt with liberal rights to affirm life, liberty, property, and family (Bosanquet, 1899; Green, 1895), by the 1910s younger idealists were discussing the necessity of recognizing certain economic and social rights as well (Haldane, 1918; Hetherington \& Muirhead, 1918; Jones, 1920). Their increased interest in the conditions of the poor and the rights necessary to elevate them from destitution was reflective of a socialist challenge to the free market economy and liberals' efforts to construct a satisfactory middle-way position that would address the problems of the poor without compromising basic liberal values. For some British liberal intellectuals-such as new liberals L. T. Hobhouse and J. A. Hobson and British idealists J. S. Mackenzie, R. B. Haldane, J. H. Muirhead, H. Jones, and H. J. W. Hetherington-the language of rights proved useful as an instrument to address the moral legitimacy of demanding state action in assistance of the poor while maintaining the vital importance of private property for individual freedom and self-realization (Freeden, 2005, pp. 49, 88).

Moreover, the liberal intellectuals' appeal for the recognition of the rights of the poor produced a shift in the liberal conceptualization of the state and poverty. As poverty began to be perceived as an outcome of inequal social and economic conditions rather than a moral defect of the poor, the state was gradually transformed from a constant threat of oppression to a benevolent authority that was both responsive and attentive to the needs of its citizens. Freeden noted this double shift in intellectual thought as "the ideology of modern welfarism was beginning to take shape" in Britain (2005, p. 88).

The literatures on the history of welfare state and social citizenship, when they have addressed British idealists' work, have focused either on Green's contributions to the ideal of social citizenship or Bosanquet's defense of laissez-faire economics against welfare proposals (George, 2010; Heater, 2006; Sullivan, 2007; Morrow, 2011). Such limited readings of British idealism resulted in a black-and-white depiction in its relation to economic and social rights. It was either Green's moral idealism that emphasized the state's social and economic responsibilities to its citizens or Bosanquet's individualistic idealism that placed the responsibility and blame for poverty and destitution on citizens themselves.

This article argues for a more nuanced way of reading the British idealist approach to the matter of economic and social rights that developed a comprehensive and structured response to the questions of poverty, economic rights, and the state's corresponding duties-namely, J. S. Mackenzie's (1860-1935) work on the matter from 1890 to 1928. Like many other British idealists of his generation, Mackenzie had a continued interest in striking a balance between the rivaling economic theories of his time: socialism and individualism. He was exceptional among the British idealists in his detailed instrumentalization of the idea of human rights in defense of citizens' rights to social and economic well-being all over the world.

A closer reading of Mackenzie's defense of his comprehensive understanding of human rights not only offers a broader understanding of the British idealist theory of human rights but relates to ongoing discussions on the place of economic and social rights within the wider domain of human rights. Economic and social rights have long been criticized for being markedly idealistic, unreasonably costly, or guilty of diluting the vital importance attributed to human rights. Alternatively, they have been treated as new additions to the regime of human rights that were developed by the communist bloc as an alternative to the West's tradition of civic and political rights. By embracing a teleological conception of human nature that unites the vegetative, animal, and truly human aspects of the individual, Mackenzie argued that rights were to be defined and 
revised when necessary to ensure that every individual had the necessary powers to pursue selfrealization.

By the 1920s, Mackenzie, in conjunction with several other British liberal intellectuals, considered the protection of individuals from the encroachment of the state through liberal rights to be insufficient for securing a reasonable chance for self-realization. Rather, he argued that individuals' rights to education, employment, maintenance, and leisure must also be recognized and protected by the state, alongside their civic rights to life, liberty, property, and franchise, so that the needs that arise from their multifaceted human nature could be met. According to Mackenzie, there was no fundamental difference between these two set of rights, except the historical circumstances that gave rise to the social and political understanding of their necessity for individual self-realization.

The first part of this article offers an overview of the liberal intellectual discussion on poverty, welfare, and economic rights with an emphasis on more seasoned British idealists' approaches to the matter. The second section addresses Mackenzie's definition of human nature and its implications for the regulation of the economic, cultural, and political spheres of human social organization. The third section discusses in greater detail Mackenzie's list of human rights, including the rights to life, liberty, property, franchise, education, employment, maintenance, and leisure. The fourth investigates the extent of Mackenzie's holistic approach and how its application to human rights may contribute to contemporary discussions on the nature and scope of human rights.

\section{Class, poverty, and British intellectual thought}

As early as the 1870 s, British intellectuals had become aware of the plight of the masses that were crushed under the adverse effects of "rapid population growth, industrialization, expanding conurbations and overseas threats to Britain's manufacturing dominance" (Humphreys, 1995, p. 50). Whereas some intellectuals blamed the capitalist economic structure and the state that enabled it for abandoning less capable individuals to brutal market forces, others assigned guilt to the poor for lacking the moral qualities necessary to lead a productive life. According to Freeden, in the early twentieth century there were four distinguishable liberal conceptualizations of poverty. Whereas the first two found the fault of poverty on the part of the individual by associating it with criminality or an immoral character, the latter two questioned the social and economic system in which certain individuals were barred from adequate income or a wider range of social benefits (Freeden, 2005, p. 61).

During the period when Mackenzie produced the majority of his work (from 1890 to 1930s), the British intellectual sphere presented a broad range of positions, from Marxism to socialism, Fabianism, new liberalism, and idealism. Whereas Marxist and socialist circles discussed the possibility of eschewing private property and establishing a form of common or communal ownership of production, Fabians oscillated between adhering to an overall challenge to the established economic system and working through the political mechanisms to better represent workers' interests (Bevir 2011, p. 18).

During the interim, new liberalism was a significant force in defense of the rights of the working class by the turn of the century. New liberal reformists, including Hobson and Hobhouse, along with New Liberal politicians such as Henry Campbell-Bannerman and Herbert Asquith were forefront figures in defending the responsibility of the state toward safeguarding the social and economic security of its citizens (Tyler, 2017, p. 133). Although the associations between new liberals and British idealists remains a topic of debate, it is reasonable to argue that, regarding the problem of poverty and its possible solutions, most idealists held a position similar to new liberals and defended the necessity for the state to take action through welfare programs.

Whereas earlier idealists such as Green and Caird had been active in education and land reform, a younger generation of idealists-including Jones, Muirhead, Haldane, Hetherington, 
and Mackenzie-paid increasing attention to the necessity of recognizing a new set of rights to elevate the conditions of the urban poor in twentieth-century Britain (Boucher 2001, p. 12; Den Otter, 2007, p. 150; Freeden, 2005, p. 95; Offer, 2006, p. 118). Humphreys (1995, p. 150) summarized it this way: "Idealists came to believe that for many poor people, inhibited by negative constraints, aspects of the cherished freedoms had been illusory with life little more than ceaseless drudgery."

Inequalities perpetuated by a system of unregulated market economy were to be eliminated by state regulations. Idealists believed the duty to eliminate extreme poverty was the responsibility of the state, and they expressed a belief in the moral legitimacy of certain economic rights for citizens. For example, Lord Haldane (1918, p. 10) defended the right to "living wage, and a decent house." Similarly, Hetherington and Muirhead (1918, p. 152) supported the idea of state guarantee for a minimum wage.

Among the British idealists, Bosanquet has been identified as an exception on this matter, especially in contemporary literature on welfare state and social citizenship. Bosanquet and the Charity Organization Society are continually criticized for overly emphasizing the responsibilities of the poor while ignoring the structural causes of poverty in a laissez-faire economy (George, 2010; Heater, 2006; Humphreys, 1995; Offer, 2006; Plant, 2006; Tyler, 2010, p. 13). Bosanquet's emphasis on the dangers of strengthening the "pauper spirit" of the poor by releasing them from the duty of leading a responsible life has been perceived as a clear sign of his total support for laissez-faire economics (Bosanquet, 1910, p. 398; Humphreys, 1995, pp. 150-152; Sullivan, 2007, p. 34$){ }^{2}$

Admittedly, Bosanquet's understanding of the causes and possible solutions for poverty deviated to a certain extent from other idealists, especially when his discussion focused on the spiritual qualities of the individual rather than the shortcomings of the social and economic system. This, in turn, is reflected in the current literature with a simplified juxtaposition of Green's and Bosanquet's approaches, with little attention given to the works of younger idealists. Considering that younger idealists such as Jones, Muirhead, Hetherington, Haldane, and Mackenzie produced a substantial amount of work in the first decades of the twentieth century, when the topics of urban poverty and unemployment dominated the intellectual discussion, a singular focus on the works of Green and Bosanquet indicates a major limitation of our consideration of the matter. Among the younger British idealists, Mackenzie's writings deserve further examination, as they present a rare, systematic instrumentalization of the concept of human rights in defense of the rights of the poor.

\section{Mackenzie on human nature and human needs}

John Stuart Mackenzie was one of the most prolific writers amongst the British idealists, and his work has not attracted enough attention. He was born in Glasgow in 1860 and, in 1877, he attended Glasgow University and studied under Edward Caird and Henry Jones. ${ }^{3}$ After his travels to Germany-where he attended lectures delivered by Wagner, Simmel, and Treitschke-he continued his education at Cambridge (Mackenzie, 1936, p. 46). After holding teaching positions at Edinburgh, Cambridge, and Manchester Universities, Mackenzie became a professor of logic and philosophy at University College in Cardiff (Mackenzie, 1936, p. 77), where he became involved in social work through the university settlement movement. He witnessed first-hand the hardships of poverty when he "moved with his wife from their comfortable suburban home to live in the working district of Splott" (Holland \& Scourfield, 2015, p. 83). Mackenzie's wife, Millicent (1936, p. 79), "was the first woman to be appointed on the regular College Staff in a British University" and described his involvement in university settlement movement this way:

$[\mathrm{H}] \mathrm{e}$ was strongly impressed by the duty laid upon a University to enter into friendly relations with all citizens, and especially with those engaged in manual labour. For many years he was treasurer of the 
University Settlement. ... The mere attending of meetings, held at the Settlement on the East Moors, Cardiff entailed much fatigue after a long day's work, but he never failed to give the necessary help, although business affairs were always uncongenial to him.

In addition to his practical involvement with groups that aimed to elevate the conditions of the working poor, Mackenzie maintained a theoretical interest in the ongoing, popular controversy between socialism and individualism from the 1890s onward.

Mackenzie's approach to the question of poverty and the state's responsibility to tackle it was an evolving one. A close reading of his work from 1890 onward shows that his sympathy for the socialist position grew continually. Although he was hesitant to endorse socialism as a superior position to individualism in the 1890s, he perceived an ultimate value in addressing the problems socialism highlighted. In Introduction to Social Philosophy, he wrote, "the evil against which Socialism is a protest, is that which we have already noted as one of the most characteristic misfortunes of the present time-the exploitation of human life by material conditions" (Mackenzie, 1895 , p. 324). He supported a certain level of socialistic regulation to fight this evil and argued the following:

Perhaps at the present time it is chiefly in the socialistic direction that advance is demanded. But the reason is simply that in recent generations the individualistic side has been too strongly insisted on. ... The problem of the next age is rather that of providing a truly human life for those who are less skilled and capable, and who are consequently less able to look after their own interests. (Mackenzie, 1901, p. 327)

In A Manual of Ethics, Mackenzie (1901, p. 412) described the existing social order as one in which the poor were exploited by the rich and reduced to dishonorable means as they did not have true liberty to make a choice between good and evil. Furthermore, the moral development of the poor was stunted as they were used "as a mere means for the advantage of others," and "they have no leisure for culture and are exposed to many temptations" (Mackenzie, 1901, p. 412). In his Lectures on Humanism, which were originally delivered as part of the Gifford lectures at Edinburgh University, he asserted, "[I]t seems clear that the old economic ideal of laissez faire is hardly compatible with the humanistic point of view" (Mackenzie, 1907, p. 124).

Although he did not have a clear alternative to the laissez-faire economics, Mackenzie (1907, p. 127) suggested that the state's responsibility toward its citizens to prevent poverty was inclusive of but not limited to education and occupational training. Furthermore, he noted that there must be duty holders beyond the nation-state if all individuals were to be guaranteed the necessary education and training for self-realization. He wrote that along with the state both "private initiatives" and "international agencies" could be perceived as partakers in the mission to prevent exploitation and poverty (Mackenzie, 1907, p. 127). Yet his comment on the possibility of an international organization remained a side note until the end of World War I, and his work focused on the responsibilities of states to recognize and maintain their citizens' rights.

Mackenzie's main argument in defense of the state's duty to protect its less fortunate citizens resembled Green's argument. When material conditions prevented individuals from fulfilling their potential, their rights to liberty became fruitless. Similar to Green, Mackenzie perceived human beings as a synthesis of higher and lower natures. Although individuals' most important moral duty was to realize their highest nature-the nature that was truly human-their lower nature was also a part of their existence that could not be ignored. According to Green (1906, p. 78), a human being was a combination of an animal organism and an eternal consciousness. Green perceived the animal organism as an inescapable inconvenience for humanity that served as a vehicle for the self-realization of the eternal consciousness. While eternal consciousness needed a vessel to channel its will toward actual things and phenomenon for its realization, the impulses of the animal organism made human beings susceptible to certain natural needs and desires. Although it was impossible for human beings to shed their animal bodies and become pure consciousness, the true meaning of being human was sought not in bodily needs but in rational and moral endeavors (Green, 1906, p. 250). 
In Outlines of Social Philosophy, Mackenzie deviated from Green's dual description of human nature and opted for a tripartite one. He argued that we were to "think of the life of man as having three main aspects-a vegetative aspect, an animal aspect, and an aspect that is more peculiarly his own" (Mackenzie, 1918, p. 33). Thus, Mackenzie (1918, p. 33) defined a human being as "a plant, with highly complex animal characteristics superadded, crowned with the potentiality of thought and with all that thought implies." Like plants, human beings needed nutrition, shelter, and reproduction for their survival. Like animals, humans were highly responsive to their environment and to those with whom they shared that environment. They had complex emotions and a certain level of intuition that enabled them to maintain relations with one another. Finally, human beings were distinguished from other life forms based on their capacity to reason. Through cultivating and using their reason, they were able to strive for development in culture, science, technology, philosophy, and art. Contrary to Green's perception of animal attributes as an inescapable hindrance to truly human qualities, Mackenzie perceived all three aspects as fundamentally constitutive. He claimed that "the glory of human life depends on this complexity," although this complexity was also "the source of our difficulties and sometimes our degradation" (Mackenzie, 1918, p. 33). According to Mackenzie, the purpose of social philosophy was to envision a system in which all individuals would be able to realize their human potential while not being deprived of the fulfillment of their vegetative and animal needs.

Mackenzie (1918, p. 38) acknowledged the apparent similarity between his description of human nature and "the threefold division" in Plato's Republic. What Mackenzie described as the vegetative aspect paralleled Plato's industrial class, and the animal characteristics he described resembled Plato's military caste. The truly human characteristics defined by the capacity for reason and morality were embodied in Plato's philosopher kings. What distinguished Mackenzie's account of human nature from Plato's was that he rightly applied his three-part division to the nature of human beings, whereas Plato turned this division into a social and political system defined by rigid social classes. Contrary to Plato's strict, categorial division of individuals, Mackenzie (1918, p. 39) stated, "[T]hough different persons may be mainly employed in providing for the satisfaction of different needs, it can hardly be said to be natural that any class should be occupied exclusively with one aspect of life." Consequently, maintaining an organic unity of individuals within a society became impossible due to a lack of understanding and empathy among different social classes. In a strictly divided society, "the lower classes would not understand the higher; and the higher, however well-educated and well intentioned, could have but little genuine sympathy with the lower" (Mackenzie, 1918, p. 39).

Although Mackenzie rejected Plato's structure of dividing individuals into classes in accordance with the ends toward which they were working, he did not deny that different aspects of human nature led to different forms of social organization. In Ultimate Values, Mackenzie contended that the economic sphere was customarily a reflection of humans' vegetative side. The political organization that enabled human beings to act as a group was attributed to their animal side, and humans' devotion to "moral, intellectual, and spiritual endeavor" was accredited to their truly human side (Mackenzie, 1924, p. 179). For Mackenzie (1924, p. 157), the true value of human existence stemmed from its mental and spiritual aspect, which was unique in its incorporation of "love, wisdom and creative power," and it was most evident in the cultural sphere. However, the economic and political spheres were no less important to human life, as it would be impossible for individuals to realize their spiritual capacities without taking part in political and economic cooperation. Mackenzie (1928, p. 283) defined these three distinct spheres this way:

The spiritual aspect is the finest, the most sublime, and the most truly human. The industrial is the most necessary, the most pressing, the most universal: without it, in some degree, life cannot be carried on at all. 
But the political aspect is the most commanding. The State is essentially a benevolent Power directed to the maintenance of all the values, both intrinsic and instrumental.

Although Mackenzie's identification of the economic sphere with the vegetative side and the moral/cultural sphere with the truly human side was unambiguous, his identification of the animal side with politics was independent from the idealist approach. In Plato's work, truly human attributes were found in the philosopher kings, who were the political agents in the society. Similarly, Green perceived politics as a direct reflection of human beings' moral nature, which enabled individuals to come together in political communities and pursue a common good. From an uncharacteristically realist position, Mackenzie argued that politics was primarily ruled by power relations among human beings in keeping with their animal nature. Yet he maintained that, although stemming from the animal characteristics of human beings, politics was often guided by the truly human attributes of reason and morality. With reference to Aristotle's "political animal," Mackenzie (1897, p. 31; 1928, p. 120) argued that politics was a sphere that was strongly conditioned by ethics and thus qualitatively different from other forms of animal coexistence. On the Aristotelian evolutionary ladder of sociality, human political organizations were higher expressions of animal forms of social coexistence in relation to how their power relations were refined by moral considerations $(1924$, p. 72$)$.

Mackenzie defined the state (i.e., the main actor in the political sphere with reference to the power it held over its citizens) and argued that a state's power was conditioned by its moral duties toward the community. Thus, Mackenzie (1928, p. 284) perceived the state as the benevolent "[p]ower directed towards the promotion of the Common Good." He was adamant that the only legitimate end the state could pursue with its power was the common good of the society (1928, p. 303). For Mackenzie, the common good maintained a social order in which individuals had a reasonable chance of realizing their full potential and pursuing their human interests. He argued that, although the state was in possession of power, it should not directly employ physical force to achieve its moral end habitually. Restating the idealist point that moral action could only stem from the individual him- or herself and cannot be induced from external sources, he (1928, p. 303) asserted that, instead of forcing individuals to act morally, the state would use "negative" force to regulate the interactions among its citizens so that each individual would have a reasonable chance and an incentive to pursue a moral life.

Although Mackenzie's preference for the state's use of negative force resonates with arguments for limiting state's sphere of influence, he did not support a minimalist state perspective. On the contrary, he argued that the state's duties were not limited to "removal of hindrances," as other British idealists suggested (Mackenzie, 1928, p. 301). He asserted that in order to sustain an orderly social coexistence, the political sphere had to retain a level of control over the cultural and economic spheres. Against those who defended the complete independence of economic and cultural spheres from political regulation, Mackenzie (1928, p. 301) wrote this:

\footnotetext{
Those who think that the three aspects of the Commonwealth-the cultural, the economic, and the political-should be kept rigidly separate compartments are, of course, opposed to any direct State control either of general education, of religion, or of industry. ... Even writers such as Green and Bosanquet, who assign a larger place to the State as an expression of the General Will of the community, consider that it is best that the State should confine itself, in general, to the 'removal of hindrances' to the cultural sphere. If we are right in thinking that it is important to recognize the oneness of the Commonwealth, as well as its triplicity, it seems clear that this negative function should not be unduly stressed.
}

Emphasizing the state's role as a benevolent power, Mackenzie maintained that it was the state's duty to "provide Goodness with the instruments that are necessary to make it effective" (1928, p. 284). The state held an efficient toolset at its disposal. Consistent with Green's wellknown thesis (i.e., out of every relation between two human beings arise certain moral rights and obligations), Mackenzie argued that rights existed before they were acknowledged by the state (Green, 1895, pp. 33-35; Mackenzie, 1928, p. 304). He claimed that, "among human beings at 
least every power and every form of social relationship may be said to bring with it some specific rights and obligations without the need of any external authority" (Mackenzie, 1928, p. 304). Yet, such rights often lacked power when they existed merely as moral rights. According to Mackenzie (1928, p. 284), the state, as the holder of benevolent power within its borders, had the obligation to supply the force necessary for the maintenance and protection of such rights. Furthermore, the newly established League of Nations and the resulting sentiment of international cooperation offered new opportunities for an international system of citizens' rights (Mackenzie, 1928, p. 277).

\section{Mackenzie's list of human rights}

In his 1928 book Fundamental Problems of Life, Mackenzie developed a system of international human rights that would ensure that each state maintained a well-ordered society in which all citizens had a reasonable chance to participate in the economic, political, and cultural spheres of life. The civic and political rights in Mackenzie's list of human rights encompassed rights to freedom, property, protection, franchise, and education. These rights were recognized by other prominent British idealists, including Green (1895, pp. 148-156, 211-232) and Bosanquet (1899, pp. $72,232 ;)$. Yet the rights that aimed to protect an individual's social and economic well-being were defended in a haphazard manner by the earlier scholarship of British idealists (Haldane, 1918, pp. 9-10; Hetherington \& Muirhead, 1918, pp. 184-187; Jones, 1909, p. 120).

Mackenzie's list of human rights, in contrast, included three specific rights intended to regulate the economic sphere (i.e., rights to employment, maintenance, and leisure). Mackenzie argued that these rights were to be accepted as fundamental and international rights to guarantee that individuals had a reasonable chance of satisfying all their needs and capacities in all three fundamental spheres of life. In accordance with his own personal observations of the conditions of the poor in Great Britain, Mackenzie's proposed list of human rights mostly addressed the needs of manual laborers in an industrialized society.

With reference to the ongoing discussion on the legitimacy of property rights between the socialists and liberals, Mackenzie (1928, p. 273) argued that the real conflict in industrial organization was between the ideals of liberty and equality. Whereas the established liberal conception of rights put singular emphasis on the right to liberty-including liberty to own and use property-as a basic condition for individual self-expression and self-realization, the socialist and communist positions maintained that equality must ensure that all individuals have access to certain material means. Situated between these two positions, Mackenzie's proposed economic human rights aimed to protect the hired laborers' equal claim to self-realization without abandoning the liberal right to property. This middle-way position proposed by Mackenzie (1928, p. 313) could be achieved through the "gradual reorganization of methods of industry" so that the principle of liberty incorporated within the right to property would be accompanied by "the fulfilment of the obligations that it implies" for the common good of the society.

According to Mackenzie, the hardest economic human right to establish and maintain was the right to employment, which was vital in two respects. First, the right to employment was a precondition for the right to maintenance. The general population that had the ability to work was required to maintain themselves and their families through a decent wage earned with their labor. Second, and most importantly from the idealist position, labor was an integral part of human self-realization. The fruits of a person's labor were valuable not only for their function but also as an expression of the individual's will and unique contribution to humanity. Mackenzie believed that in its highest form labor was creative and seemed "to be the very end of human existence" (Mackenzie, 1918, p. 183). In this regard, fluidity occurred between the industrial and cultural spheres. When labor-be it mental or manual—was best adapted to the qualities of the individual, 
it was elevated from mere drudgery and became a path toward an individual's self-realization (Mackenzie, 1928, p. 207).

Contrary to scholars who perceived unemployment as a sign of individual moral defect, Mackenzie argued that the inability to find suitable employment often resulted from swift changes in the market and not from the idleness of the poor. Especially "owing to the progress of invention," certain areas of expertise were becoming obsolete, forcing large numbers of individuals into unemployment. Mackenzie asserted that although the right to employment undeniably placed several obligations on the individual him- or herself (such as being willing to work and to prepare for useful employment to the best of one's abilities) the hardships an individual faced in the economic sphere were often unsurpassable by individual effort alone. For that reason, the right to employment bestowed certain responsibilities on the "bodies that are concerned with industrial organization," including the state (Mackenzie, 1928, p. 220). Whereas under normal circumstances the state had the duty to educate and train its citizens so that they could find the vocation that was best suited for them, under extraordinary circumstances, Mackenzie (1928, p. 316) argued that the state might provide temporary relief to the unemployed through schemes of communal work or through labor exchange programs. Contrary to his fellow idealist Jones, who believed that the "workhouse" was proof that the state already recognized the right to employment, Mackenzie maintained that workhouse labor was mostly useless and not contributory to individual self-realization (1928, p. 317).

Mackenzie recognized maintenance as another fundamental economic right that was essential for the self-realization of individuals. He argued that, to be able to live a life conducive to the realization of human potential, individuals must have a minimum standard of living conditions. Mackenzie (1918, p. 157) asserted that the most important of these conditions was a "suitable house accommodation" that includes "a suitable supply of water and light." Thus, he believed that the state had a duty to "do something to provide suitable accommodation" to its citizens (1918, p. 157). However, the human right to maintenance did not amount to unlimited charity from the state to its citizens as passive recipients. On the contrary, Mackenzie believed the most sustainable way to uphold the human right to maintenance was to ensure that individuals earned enough to maintain themselves and their families through their own labor. He perceived the solution as regulating the minimum wage so that hired laborers would not be forced to work and live in degraded conditions. Clearly, Mackenzie was aware of the possibility that under adverse market conditions individuals would be forced to accept employment with inadequate pay out of sheer desperation. Thus, the right to maintenance imposed "grave responsibilities both upon the individuals who claim it and upon the bodies that are concerned with industrial organization" (Mackenzie, 1928, p. 317).

The last economic right in Mackenzie's list was the most controversial one-the right to leisure. Mackenzie argued the right to labor gave rise to the right to leisure as its logical counterpart. He defined leisure not merely as idleness or physical rest. He meant that individuals would have a reasonable amount of time left from work to attend to the multifaceted necessities and interests in their lives. Accordingly, leisure included "rest and recreation," but it was not limited to them. Mackenzie (1928, pp. 317-318) argued:

[The laborer] works to live and to help others to live; but he does not merely live to work. He is a member of a family ... he belongs to a particular neighborhood and to a particular nation; and he has some responsibilities for the general life of the communities to which he belongs.

When the working periods of waged laborer were not regulated, there was the risk that individuals' labor would encompass the entirety of their lives, and they would not have the opportunity to devote sufficient attention to other responsibilities and interests as members of various cultural and political communities. Nevertheless, for Mackenzie (1928, pp. 317-318), there was an even more important reason for recognizing individuals' right to leisure: 
A human being needs rest and recreation, just as an animal does; and he needs also, as the animal does not, opportunities for the cultivation of the intellectual and more purely spiritual side of his nature. The citizen is not merely a being with one particular vocation. ... He is responsible also for his selfdevelopment. It is these obligations chiefly that make leisure a necessity, and the right to it depends on its being employed, at least partly, in their fulfilment.

For Mackenzie, leisure meant the time spent to improve oneself in versatile interests that serve an individual's self-development. Acknowledging the existence of different forms of labor divided into physical and intellectual work, he (1928, p. 282) argued, to a great extent, that leisure encompassed "a change of occupation." He wrote "in so far as a man's work is mainly cultural, his relaxation tends to be largely physical; and, so far as his work is mainly physical, his relaxation may be expected to be largely cultural" (Mackenzie, 1928, p. 282). To enable individuals to exercise their right to leisure, the state had the duty of limiting the hours of labor (1928, p. 282). Furthermore, the state had the obligation to offer the basic means for individuals to pursue certain cultural interests. Among such services, Mackenzie (1918, pp. 121-128) listed the necessity for a national library, a national museum, and a national theater or picture gallery. With access to such communal services, citizens would have the opportunity to develop their higher interests, which come from their truly human nature.

In addition to these economic rights, Mackenzie maintained an emphasis on the primacy of the right to education. Education was "necessary for the realization of the rational self," which was a precondition for the enjoyment of all other rights-economic or political (Mackenzie, 1901, p. 319). For young citizens, education was a transition period from the family to a larger community, and it was the state's responsibility to constitute an adequate educational system that was accessible to every child. While education in science and technical and vocational training were vital for those individuals who were to enter the workforce, education in the humanities and ethics was indispensable for the entire population, as individuals needed a basic knowledge of their rights and duties within their social and political community (Mackenzie, 1924, p. 170; Mander, 2011, p. 272).

\section{Discussion}

Regarding his concern for the economic and social rights of the working class, Mackenzie was not an outlier at the turn of the twentieth century. In the decades preceding World War I, the middle-class public's understanding of the causes of poverty principally focused on possible structural issues instead of the moral quality of the poor. The middle class became increasingly conscious of "large numbers of underemployed, sick and old people living in poverty, the majority of whom were poor because of economic circumstances rather than personal failure" (Boyer, 2018, p. 11). Inadequate economic circumstances encompassed not only a lack of employment opportunities but also insufficient wages in sweated industries and defective housing (Boyer, 2018, p. 169; Rodger, 1989, p. 1; Searle, 2004, p. 305).

The increasing public awareness was swiftly translated into political action at the turn of the century. With the Liberal Party's ascent to power in 1906 and under new liberal Prime Ministers Campbell-Bannerman and Asquith, several boards were established to analyze the basis of poverty among the working class and to form legislative solutions to problems such as unemployment, inadequate pay in sweated industries, lack of old-age pensions, and health insurance for sickness and injury. Overall, "the Liberal Welfare reforms represented a sharp about-face in British social policy after seven decades of increasing stinginess toward the poor" (Boyer, 2018, p. 151). Furthermore, during the economic downturn of the interwar years, and especially due to the steep rise in unemployment, existing welfare programs were employed more commonly and were normalized in public perception. 
However, until after the end of World War II, existing welfare programs did not amount to a comprehensive welfare system that protected a citizen's economic and social rights. The aspiration for international economic and social rights was first codified by the United Nations in Articles 22 to 25 of the Universal Declaration of Human Rights in 1948. Following years' worth of heated discussions on the status of economic and social rights as human rights, a separate "International Covenant on Economic, Social and Cultural Rights" was drafted in 1954, and it was ratified by the UN General Assembly in 1966 (Kirkup \& Evans, 2009, p. 226-232).

By the turn of the twentieth century, within the British intellectual sphere, the problem and solutions regarding poverty were discussed as a matter of right (Offer, 2006, p. 118; Seaman, 1978, p. 789; Whelan \& Donnelly, 2007, p. 944). Elsewhere in the world, concern for the conditions of the poor, greatly elevated first by World War I and later by the Great Depression, was coupled with an increased optimism related to the possibility of envisioning a system of international rights maintained by the League of Nations (Finch, 1941; Hetherington, 1920; Winter \& Prost 2013, p. 51; Worland, 1991, p. 624). Nonetheless, the discussion on the matter amounted only to a proto-human rights discourse that did not necessarily include economic and social rights.

Within this intellectual setting, Mackenzie occupied an almost singular position that enabled him to envision an international system of human rights inclusive of the rights to employment, maintenance, and leisure. As a British idealist, his life-long work on political theory revolved around a teleological conceptualization of rights that was justified with reference to human beings' moral end of self-realization; consequently, it was universalizable beyond state-borders. Moreover, the actual content of rights according to Mackenzie was highly responsive to the social, political, and economic conditions in which individuals pursued the moral end of self-realization. Mackenzie (1928, p. 347) argued, "[W]hat a modern writer had to try to do is to give some account of the complex conditions that are involved in the communal life, and to indicate how it may be possible gradually to remove the difficulties that are involved in them."

Thus, from Mackenzie's perspective, there was no fundamental difference between political rights and economic rights. All rights were necessary powers for individuals to have the opportunity for self-realization. Accordingly, his list of rights was not divided into subgroups but were presented as "some of the chief rights that have been commonly claimed for [individuals]" (1928, p. 312). In addition to the already established liberal rights of life, liberty, property, and franchise, the economic and social rights to education, employment, maintenance, and leisure were deemed necessary for an individual's self-realization. Evidently, Mackenzie believed the changes in social and economic conditions of the nineteenth and twentieth centuries, especially with the industrialization of production, brought a need for the recognition of a larger set of rights.

Mackenzie's interest in the writings of prominent economists and intellectuals of his contemporaries-both socialist and liberal-also contributed greatly to his discussions on the matter. His approach to economics and to the nature of value reveals that he was particularly impressed by John Ruskin's reevaluation of the concept of value and Alfred Marshall's argument for "placing the abolition of poverty, rather than the increase of wealth, as the foremost problem in economics" (Mackenzie, 1893, p. 295; 1928). Together, the works of Ruskin and Marshall prioritized welfare instead of wealth, and for Mackenzie, this was a great leap forward in the field of economics. This novel approach to economics was in agreement with the basic tenets of British idealist philosophy, as both perceived material goods as a means for the moral end of human self-realization and also perceived the necessity of a certain degree of equality in individuals' access to such means.

Mackenzie's concern for the conditions of the poor, coupled with his favorable perception of the work of the League of Nations in the 1920s, led him to develop a British idealist theory of human rights. He argued: 
[R] eflection on the various rights and obligations that come to light in the development of the communal life tends to convince us that they rest on the fundamental nature of man, and consequently do not depend on any particular circumstances of nationality; though, no doubt, they may be greatly modified in detail by local and historical conditions. (Mackenzie, 1928, p. 318)

According to Mackenzie, the Hague Conference and the League of Nations "pointed the way forward in practice," but it was necessary to develop a broader perception of international cooperation (1928, p. 319). He contended that "the concentration of attention on the improvement of methods of industrial organization creates the desire for international peace, and that any failure to secure satisfactory economic conditions in different countries renders the attempt to secure any genuine international unity extremely precarious" (Mackenzie, 1928, p. 277). For Mackenzie, the protection of rights was not merely a concern for nation states but also an international matter that was to be considered and, if possible, overseen by newly founded international organizations.

The question of legitimacy or necessity in recognizing economic and social rights as human rights alongside more dated civic and political rights has been a long-standing issue of contention, and several theoretical and historical explanations have been offered to reveal the insurmountable differences between these two sets of human rights. It was argued that (1) economic and social rights were not justiciable compared to political and civil rights; (2) political and civil rights preceded economic and social rights historically, and thus the second set of rights was not yet properly established as human rights; (3) the West was traditionally the defender of political rights, whereas the Soviet bloc favored economic and social rights; and (4) economic and social rights were exceedingly costly as they were positive rights, whereas political and civil rights required minimum state effort for protection as they were negative rights (Koch, 2009, p. 5; Whelan \& Donnelly, 2007, p. 946).

Beyond these considerations, the legitimacy of economic and social rights was questioned with reference to the central objective of human rights. Those who perceived human rights as the definitive safeguard for an individual's survival identified economic and social rights as the unnecessary tempering of the human rights paradigm. Milan Kundera (1990, p. 136) offered his famous criticism of economic, social, and cultural rights in Immortality:

The more the fight for human rights gains in popularity, the more it loses any concrete content, becoming a kind of universal stance of everyone towards everything, a kind of energy that turns all human desires into rights. The world has become man's right and everything in it has become a right: the desire for love a right to love, the desire for rest a right to rest ... the desire to shout in the street in the middle of the night the right to shout in the street.

Kundera believed that inclusion of new items into the list of human rights stole from the definitive authority of the concept and decreased its appeal in cases in which individuals' actual survival depended on them. Kundera's argument resonates with many who perceived of human rights as tools to be used as a last resort when every other moral and political process fails in protecting human beings from extreme degradation (Nickel, 2005, p. 386). Any vision that ascribes to human rights a role that goes beyond ensuring minimal survival is identified by these scholars as an attempt to belittle the last defense of human dignity. This tendency led to the assessment of human rights as a set of norms that saves individuals only from the cruelest and most damaging treatments, such as genocide, ethnic cleansing, and systemic torture (Nickel, 2005, p. 391). ${ }^{4}$ The rest-the kind of life individuals are able to lead-was not to be taken as a concern within the scope of human rights paradigm, and human degradation that results from unintentional actions on the part of the states or the market forces was not considered as a violation of human rights (Shue, 1980, p. 40).

The opposing side criticized such minimalist approaches for failing to defend a truly human existence by reducing human rights to a mere instrument for physical survival. The alternative maximalist approaches emphasized what needs to be protected in a human being, often described 
as human dignity, human potential, or human self-realization. As these approaches required an acknowledgment of "the complexity of human existence," with its multifaceted needs and potentialities, political, civil, economic, social, and cultural human rights were treated as an indivisible set of universal norms (Felice, 1999; Koch, 2009; Scott, 1999; Whelan \& Donnelly, 2007). Consequently, basic rights were differentiated from other derivative rights by asking the question which rights are the ones without which individuals cannot reasonably be expected to pursue a "minimally good life" (Nickel, 2005, p. 386). Going beyond the conventional argument to divide the human rights paradigm into two-and sometimes three-distinct groups whose importance decreases from the first to last, maximalist approaches to human rights recognize each state's duty to respect, protect, and satisfy all human rights that are imperative to pursue a truly human life (Felice, 1999, p. 568).

I argue that revisiting Mackenzie's arguments on the matter may help defenders of the maximalist position, not only because it is a rare example of the recognition of a larger set of human rights in the 1920s but also because it offers a solid theoretical account of human rights' vital importance for individual self-realization.

First, being a variation of Green's British idealist theory of rights, Mackenzie's approach supports the universality of human rights with reference to the moral nature of humanity. So far as every human being is perceived to be the bearer of a moral potential in need of self-realization, individuals are argued to have a legitimate claim for the recognition and maintenance of certain powers in the form of rights.

Second, the specific content of the powers deemed necessary for self-realization is argued to be dependent on the particular social, economic, and political conditions of the country and the era in which individuals are embedded. This practical aspect of Mackenzie's theory of rights envisions a process for expanding the scope of human rights in response to the changing or varying conditions of social and economic life when necessary. Thus, it allows for a certain level of flexibility in the interpretation and implementation of rights in accordance with the specific conditions of particular societies without drifting into a cultural relativist position. The legitimacy of an assertion of rights is judged through a consideration of the necessities that stem from the tripartite human nature and the existing impediments to an individual's ability to satisfy these needs. Through such consideration, Mackenzie argued that the rights to life, liberty, property, franchise, education, employment, maintenance, and leisure emerge as legitimate right claims that need to be recognized in every industrialized, political community.

Third, in the list of human rights Mackenzie provided in Fundamental Problems of Life, no distinction is made between political and economic rights. On the contrary, all rights are given equal attention in their examination and grounded in the same moral argument: Rights are the powers necessary for an individual's self-realization and for the common good of the society. Without their recognition and protection, individuals would not have a realistic opportunity to pursue self-realization and contribute to the common good of the society.

Fourth, all rights included in Mackenzie's list bestowed both the state and the individual with corresponding duties, and he made no distinction among these rights in regard to their corresponding duties being positive or negative. From his scholarship, it can be deduced that all human rights impose both negative and positive duties on the state and the individual, depending on the specific conditions under which they were invoked.

Finally, according to Mackenzie, protection of these rights was not merely a national matter but an international one, with significant implications for world peace and the overall welfare of humanity. Their realization in every country represented a matter of concern for international organizations if further unity and cooperation among societies were to be achieved. 


\section{Conclusion}

From 1870 onward, urban poverty dominated public, political, and intellectual discussions in Britain. In the face of the rising socialist challenge to laissez-faire economics, liberal intellectuals started to instrumentalize the vocabulary of rights in defense of the necessity of state regulation in the economic sphere. Mackenzie, along with several new liberal and idealist intellectuals of his time, held an especially favorable position for developing an account of international human rights inclusive of not only of the liberal rights to life, liberty, and property but also the newly envisaged economic rights to employment, maintenance, and leisure. Although Mackenzie's list did not exhaust all of the economic rights demanded at the time (e.g., free health care), it significantly expanded the idealist theory of rights in light of rising concerns about poverty and new developments in international cooperation.

Mackenzie's instrumentalization of the idealistic approach to tripartite human nature revealed the interdependence of human needs and interests in the economic, political, and cultural spheres of social interaction and offered a theoretical basis for state regulation of the economic sphere. Considering that the legitimacy of economic and social human rights still remains under scrutiny, his reflections on the matter provide insights into why human rights-be they political, economic, or cultural-must be taken as an indivisible set of moral norms, as each ensures that individuals have a reasonable chance not only for survival but also for pursuing a truly human life.

\section{Notes}

1. For contemporary discussions on the British idealist theory of rights, see Dimova-Cookson (2001), Boucher (2001), Darby (2009), and Nesbitt 2001).

2. For alternative-and more positive-readings of Bosanquet's position on poverty and state action, see Sweet (1999a, 1999b), Gaus (2001), and Den Otter (2007).

3. For a detailed account of his life and work, see Mackenzie (1936).

4. For a discussion of the shift in the human rights paradigm from the 1940s onward, see Meister (2011).

\section{Acknowledgments}

An earlier version of this article was presented at the 2019 Political Science Association Annual Conference, British Idealist Specialist Group Session. I would like to thank all the participants for their insightful questions and criticisms. I am indebted to Peter Nicholson for reading numerous versions of this article and offering his guidance for its improvement. I would also like to thank the referees for their meticulous reading of the article and for their invaluable suggestions.

\section{Notes on contributor}

Nazli Pinar Kaymaz received her PhD in political science from Bilkent University in 2018. She worked as a visiting researcher at Cardiff University, Collingwood, and the British Idealism Center in 2016 and as an adjunct lecturer at Bilkent and TED Universities between 2018 and 2020.

\section{References}

Bevir, M. (2011) The making of British socialism. Princeton University Press.

Bosanquet, B. (1899). The philosophical theory of the state. Macmillan and Co. Ltd.

Bosanquet, B. (1910). Charity organization and the majority report. International Journal of Ethics, 20(4), $295-408$.

Boucher, D. (2001). British idealism and the human rights culture. History of European Ideas, 27(1), 61-78. doi:10. 1080/01916599.2001.11644277

Boyer, G. R. (2018). The winding road to the welfare state: Economic insecurity \& social welfare policy in Britain. Princeton University Press.

Darby, D. (2009). Rights, race, and recognition. Cambridge University Press. 
Den Otter, S. M. (2007). The restoration of a citizen mind: Bernard Bosanquet and the Charity Organisation Society. In William Sweet (Eds.), Bernard Bosanquet and the legacy of British idealism (pp. 33-49). University of Toronto Press.

Dimova-Cookson, M. (2001). T. H. Green's moral and political philosophy: A phenomenological perspective. Palgrave.

Felice, W. F. (1999). The viability of the United Nations approach to economic and social human rights in a globalized economy. International Affairs, 75(3), 563-598.

Finch, G. A. (1941). The international rights of man. The American Journal of International Law, 35(4), 662-665. doi: $10.2307 / 2192570$

Freeden, M. (2005). Liberal languages. Princeton University Press.

Gaus, G. (2001). Bosanquet's communitarian defense of economic individualism. In Avital Simhony \& D. Weinstein (Eds.), The new liberalism (pp. 137-159). Cambridge University Press.

George, V. (2010). Major thinkers in welfare: Contemporary issues in historical perspective. The Policy Press.

Green, T. H. (1906). Prolegomena to ethics (A. C. Bradley, Eds., 5th ed.). Clarendon Press.

Green, T. H. (1895). Lectures on the principles of political obligation. Longmans, Green and Co.

Haldane, R. B. (1918). The future of democracy: An address by Lord Haldane. Headley Bros. Publishers Ltd.

Heater, D. (2006). Citizenship in Britain: A history. Edinburgh University Press.

Hetherington, H. J. W. (1920). International labour legislation. Methuen \& Co. Ltd.

Hetherington, H. J. W., \& Muirhead, J. H. (1918). Social purpose: A contribution to a philosophy of civic society. George Allen \& Unwin Ltd.

Holland, S., \& Scourfield, J. (2015). Social work: A very short introduction. Oxford University Press.

Humphreys, R. (1995). Sin, organized charity and the poor law in Victorian England. Macmillan Press Ltd.

Jones, H. (1909). Idealism as a practical creed. James Maclehose and Sons.

Jones, H. (1920). The principles of citizenship. Macmillan and Co. Ltd.

Kirkup, A., \& Evans, T. (2009). The myth of western opposition to economic, social, and cultural rights? A reply to Whelan and Donnelly. Human Rights Quarterly, 31(1), 221-238. doi:10.1353/hrq.0.0063

Koch, I. E. (2009). Human rights as indivisible rights: The protection of socio-economic demands under the European Convention on Human Rights. Brill.

Kundera, M. (1990). Immortality (Peter Kussi, Trans.). Harper Perennial.

Mackenzie, J. S. (1893). Review of socialism and the American spirit by Nicholas Paine Gilman. The International Journal of Ethics, 4(1), 120-123. doi:10.1086/intejethi.4.1.2375719

Mackenzie, J. S. (1895). An introduction to social philosophy (2nd ed.). James Maclehose \& Sons.

Mackenzie, J. S. (1897). The moral aspects of socialism. The International Journal of Ethics, 7(2), 230-232. doi:10. 1086/intejethi.7.2.2375574

Mackenzie, J. S. (1901). A manual of ethics (4th ed.). Hinds, Hayden \& Eldredge Inc.

Mackenzie, J. S. (1907). Lectures on humanism. Swan Sonnenschein \& Co.

Mackenzie, J. S. (1918). Outlines of social philosophy. George Allen \& Unwin Ltd.

Mackenzie, J. S. (1924). Ultimate values in the light of contemporary thought. Hodder and Stoughton Ltd.

Mackenzie, J. S. (1936). John Stuart Mackenzie (Millicent Mackenzie, Eds.). Williams \& Norgate Ltd.

Mackenzie, J. S. (1928). Fundamental problems of life: An essay on citizenship as pursuit of values. Allen \& Unwin.

Mander, W. J. (2011). British idealism: A history. Oxford University Press.

Meister, R. (2011). After evil: A politics of human rights. Columbia University Press.

Morrow, J. (2011). Private property, liberal subjects, and the state. In Avital Simhony \& D. Weinstein (Eds.), The new liberalism (pp. 92-115). Cambridge University Press.

Nesbitt, D. R. (2001). Recognizing rights: Social recognition in T. H. Green's system of rights. Polity, 33(3), 423-437. doi:10.2307/3235442

Nickel, J. W. (2005). Poverty and rights. The Philosophical Quarterly, 55(220), 385-402. doi:10.1111/j.0031-8094. 2005.00406.x

Offer, J. (2006). An intellectual history of British Social Policy: Idealism versus non-idealism. The Policy Press.

Plant, R. (2006). T. H. Green: Citizenship, education and the law. Oxford Review of Education, 32(1), 23-37. doi: $10.1080 / 03054980500496361$

Rodger, R. (1989). Housing in Urban Britain 1780-1914: Class, capitalism and construction. Macmillan Education Ltd.

Scott, C. (1999). Reaching beyond (without abandoning) the category of economic, social and cultural rights. Human Rights Quarterly, 21(3), 633-660. doi:10.1353/hrq.1999.0043

Seaman, J. W. (1978). L. T. Hobhouse and the theory of "Social Liberalism." Canadian Journal of Political Science, 11(4), 777-801. doi:10.1017/S0008423900046606

Searle, G. R. (2004). A New England?: Peace and war 1886-1918. Oxford University Press.

Shue, H. (1980). Basic rights: Subsistence, affluence, and US foreign policy. Princeton University Press. 
Sullivan, K. (2007). Bosanquet, perfectionism, and distributive justice. In William Sweet (Eds.), Bernard Bosanquet and the legacy of British Idealism. University of Toronto Press.

Sweet, W. (1999a). Bosanquet and British political thought. Laval Théologique et Philosophique, 55(1), 99-114. doi: 10.7202/401218ar

Sweet, W. (1999b). Preface. In William Sweet (Eds.), Essays on aspects of the social problem and essays on social policy (pp. vii-xiv). Thoemmes Press.

Tyler, C. (2010). The metaphysics of self-realisation and freedom: Part 1 of the liberal socialism of Thomas Hill Green. Imprint Academic.

Tyler, C. (2017). Common good politics: British idealism and social justice in contemporary world. Palgrave Macmillan.

Whelan, D. J., \& Donnelly, J. (2007). The west, economic and social rights, and the global human rights regime: Setting the record straight. Human Rights Quarterly, 29(4), 908-949. doi:10.1353/hrq.2007.0050

Winter, J., \& Prost, A. (2013). Rene Cassin and human rights. Cambridge University Press.

Worland, S. T. (1991). The preferential option, Pope Pius XI, and the foundations of social economics. Review of Social Economy, 49(4), 611-627. doi:10.1080/00346769100000051 